\title{
Proposition of technique modification of liver harvesting in orthotopic transplantation in pigs
}

Proposição de modificação técnica da retirada do fígado no transplante ortotópico em porcos

Marcus Vinicius Henriques Brito, Renan Kleber Costa Teixeira, Abdallah de Paula Houat, Luane Cristine Batista Cunha

\footnotetext{
Research performed at Laboratory for Experimental Surgery, Universidade do Estado do Pará, Brazil.

Financial support: none.

Conflict of interest: none

Correspondence address: Marcus Vinicius Henriques Brito, Department of Surgery, Universidade do Estado do

Pará, E-mail: mvhb@hotmail.com

Submitted: 16 february 2013. Accepted, after review: 26 march 2013.
}

\begin{abstract}
Objective: Taking into consideration the technical complexity involved in liver transplantation, the anesthetic-surgical team training has been considered a fundamental step before clinical application through experimental surgery in animals. The aim of this study is to describe the technique modification of liver harvesting in orthotopic transplantation in pigs. Methods: Seven sows Sus escrofa were used. The animals were previously anesthetized and placed in trans-operative monitoring. The harvest of the liver was performed by means of a different sequence reported by the literature, in which the liver vessels was handled in a clockwise direction. Results: The average time of hepatic harvesting was 84.4 minutes and the time of each anatomical structure dissection was considered satisfactory. Conclusion: The described technique of liver harvesting in orthotopic transplantation in pigs is viable, effective and reproducible, enabling the training of professionals and academics.
\end{abstract}

Key words: Pigs. Transplantation. Liver. Technique. Surgery.

\section{RESUMO}

Objetivo: Levando em consideração a complexidade técnica envolvida no transplante de fígado, o treinamento da equipe anestésico-cirúrgica foi considerado um passo fundamental antes da aplicação clínica através de cirurgia experimental em animais. O objetivo do estudo foi descrever a modificação técnica de coleta de fígado do doador em transplante ortotópico em suínos. Métodos. Foram utilizadas sete porcas Sus escrofa. Os animais foram anestesiados e monitorizadas para controle trans-operatório. A coleta do fígado do doador foi realizada por meio de uma sequência diferente relatada pela literatura, em que os vasos sanguíneos do 
fígado foram manipulados no sentido horário. Resultados: $\mathrm{O}$ tempo médio de coleta hepática foi de 84,4 minutos e o tempo de cada dissecção das estruturas anatômicas foi considerado satisfatório. Conclusão: A técnica descrita da coleta de fígado em transplante ortotópico em suínos é viável, eficaz e reprodutível, permitindo a formação de profissionais e acadêmicos.

Descritores: Suínos. Transplante. Fígado. Técnica. Cirurgia.

\section{INTRODUCTION}

Liver transplantation and immunosuppressants have significantly increased survival of patients with terminal chronic and irreversible liver diseases; however, the failure of transplantation is still a constant concern. ${ }^{1}$ Technical development has represented a major challenge in clinical-surgical practice, not only for its complexity but also by the shortage of available organs. ${ }^{2}$

At the University Hospital of Recife, Brazil, it was found to be possible to perform liver transplantations with good results in public hospitals of underserved regions in terms of health care, provided that there are trained multidisciplinary teams and minimum physical structure. ${ }^{3}$

Taking into consideration the technical complexity involved in liver transplantation, the training of the anesthetic-surgical team, through experimental surgery on animals, has been considered a fundamental step before clinical application. ${ }^{4,5}$

The shortage of studies describing the technique of liver transplantation in pigs and anatomical configuration analysis justifies this research. It which aims to describe the modification of procedures for hepatic harvesting in orthotopic transplantation in pigs, in order to collaborate with training and technical improvement to enlarge the anatomical knowledge and experience, thus decreasing the incidence of surgical complications.

\section{METHODS}

This research was approved by the Ethics Committee on Animal Usage of the State University of the state of Pará, carried out at the Experimental Surgery Laboratory (ESL) of this institution. The standards of the Brazilian College of Animal Experimentation (COBEA) and the Brazilian legislation in force for use and handling of animals (no. 11.794/08) were followed.

Seven sows were used (Sus escrofa), weighing between five and eight kilograms, which were housed in appropriate animal house and water and feed were offered ad libitum. In the pre-operative period, animals underwent 12 hours fasting 
before surgery. The anesthetic induction was performed with ketamine $(10 \mathrm{mg} / \mathrm{kg})$, associated with xylazine $(20 \mathrm{mg} / \mathrm{kg})$, administered intramuscularly in the area of the animal's thigh. After induction, antisepsis was performed and then the animals were intubated in order to begin maintenance of anesthesia by using halothane through inhalation. After this, cardiac monitoring of mean arterial pressure (MAP) was proceeded by means of the left carotid artery catheterization and oximetry.

The technique begined by a xiphopubic laparotomy, followed by the dissection of the abdominal aorta and its repair with cardiac tapes placed one to two centimeters above the iliac bifurcation (Figure 1, no. 1). Hepatic pedicle was handled clockwise and dissected until the emergence of the right renal vein. Subsequently, feeble repair of the infrahepatic vena cava was performed with 2-0 silk thread (Figure 1 , no. 2), followed by ligation of the tributaries of the portal vein and its repair (Figure 1, no. 3).

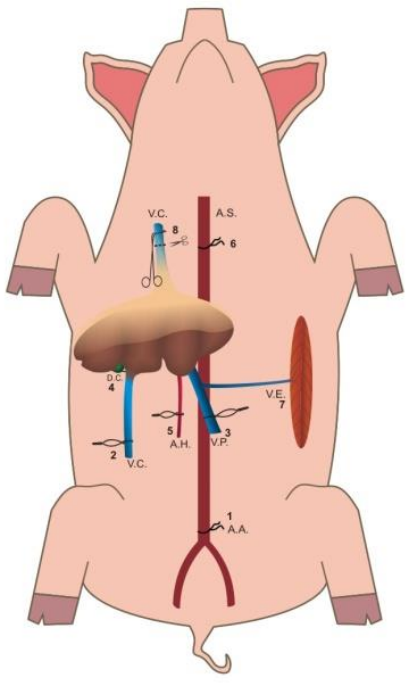

Figure 01 - Schema of operating time of donor animal.

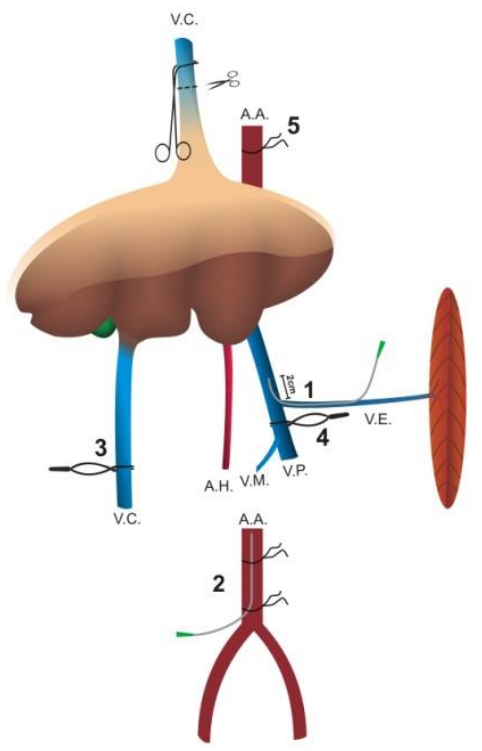

Figure 02 - Catheterization and vascular ligation of donor animal.

The common bile duct was dissected, connected and sectioned (Figure 1, no. 4). Subsequently, the isolation of hepatic artery and ligation of collateral tributaries were performed (Figure 1, no. 5). After handling the hepatic pedicle, the posterior liver ligaments were sectioned, followed by the dissection and the use of cardiac tape applied to the suprahepatic aorta (Figure 1, no. 6).

For all ligatures, 2-0 silk threads were used, except for the aorta, which was ligated with cardiac tapes. Then, dissection and repair of the splenic vein were performed (Figure 1, no. 7). Once this was done, the organ must be prepared for perfusion in situ. This way, the catheterization of the splenic vein was performed with 8 Nelaton nasogastric catheter and its tip had to be directed to the inside of the portal vein by approximately two centimeters in cranial direction (Figure 2, no. 1). Later, the abdominal aorta was catheterized with 10 Nelaton nasogastric catheter. (Figure 2, no. 2). 
In order to limit the blood flow into the liver, the ligation of the infradiaphragmatic aorta was performed on the catheter (Figure 2, no. 2). The horizontal opening of the diaphragm was performed two centimeters above the suprahepatic vena cava, causing pneumothorax. At this point, the anesthesiologist must increase the oxygen pressure. The suprahepatic vena cava was dissected through this orifice, five to eight centimeters above the diaphragm. (Figure 1, no. 8).

The infrahepatic vena cava was "clamped" with the aid of a "Bulldog" forceps (Figure 2, no. 3), as well as the bifurcation of the portal vein to the level of the superior mesenteric vein (Figure 2, no. 4). The suprahepatic aorta was then ligated, ceasing arterial flow (Figure 2, no. 5). At this stage, a perfusion of two to three liters of conservation solution to $4 \stackrel{\circ}{\circ}$ (depending on the size of the animal) was performed by the aorta and splenic vein catheters drawing the blood from the liver, starting cold ischemia, which should be timed.

Along with the start of hepatic perfusion, the suprahepatic vena cava was sectioned within the thorax, as distant as possible from the liver, allowing blood and the irrigated solution flow to the thoracic cavity. After the liver exsanguination is complete, which was denoted by liver's paleness, the release of the graft was performed. The diaphragm - which was in close contact with the suprahepatic vena cava - was sectioned in a circular format, having referred the vessel as the center. Subsequently, the section of the portal vein, the hepatic artery, and finally the infrahepatic vena cava was performed. At this stage, the graft was withdrawn and taken to the back table, ending the step of liver harvesting. After liver harvesting, euthanasia was performed on the donor animal with an intravenous $50 \mathrm{ml}$ injection of $10 \% \mathrm{KCL}$. The carcass was discharged in biological waste, according to the legislation in force.

\section{RESULTS}

The average time of hepatic harvesting was $84.4 \pm 5.63$ minutes, ranging from the time of arrival of the animal without being intubated, until the liver was prepared to go to the back table. The time of dissection of each anatomical structure is described below (Table 1). 
Table 1: Surgical times of donor animals' surgery for liver transplantation in pigs performed at the ESL, Brazil. 2012.

Donor Stages (Time)

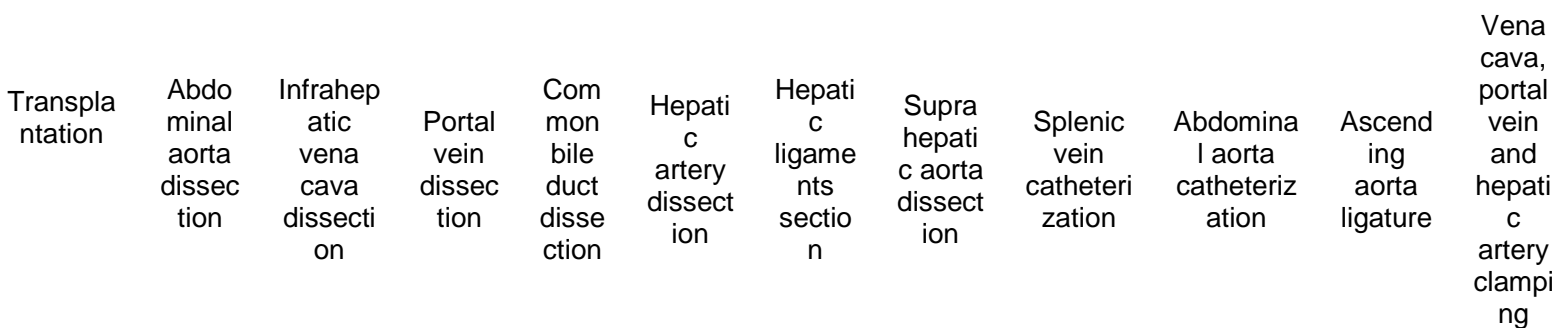

\begin{tabular}{|c|c|c|c|c|c|c|c|c|c|c|c|}
\hline 1 & $3^{\prime}$ & $1^{\prime}$ & $2^{\prime}$ & $<1^{\prime}$ & $10^{\prime}$ & $10^{\prime}$ & $1^{\prime}$ & $9^{\prime}$ & $5^{\prime}$ & $<1$ & $<1^{\prime}$ \\
\hline 2 & $3^{\prime}$ & $16^{\prime}$ & $11^{\prime}$ & $1^{\prime}$ & $2^{\prime}$ & $1^{\prime}$ & $3^{\prime}$ & $7^{\prime}$ & $1^{\prime}$ & $1^{\prime}$ & $1^{\prime}$ \\
\hline 3 & $3^{\prime}$ & $4^{\prime}$ & $3^{\prime}$ & $1^{\prime}$ & $3^{\prime}$ & $4^{\prime}$ & $3^{\prime}$ & $8^{\prime}$ & $2^{\prime}$ & $1^{\prime}$ & $1^{\prime}$ \\
\hline 4 & $1^{\prime}$ & $4^{\prime}$ & $7^{\prime}$ & $1 '$ & $4^{\prime}$ & 8 ' & $3^{\prime}$ & $6^{\prime}$ & $2^{\prime}$ & $1^{\prime}$ & $<1^{\prime}$ \\
\hline 5 & $2^{\prime}$ & $2^{\prime}$ & $20^{\prime}$ & $1^{\prime}$ & $5^{\prime}$ & $3^{\prime}$ & $3^{\prime}$ & $6^{\prime}$ & $4^{\prime}$ & $1^{\prime}$ & $1^{\prime}$ \\
\hline 6 & $4^{\prime}$ & $7^{\prime}$ & $14^{\prime}$ & 2' & $9^{\prime}$ & $2^{\prime}$ & 3 ' & $8^{\prime}$ & $3^{\prime}$ & $1^{\prime}$ & $<1^{\prime}$ \\
\hline 7 & $2^{\prime}$ & $8^{\prime}$ & $11^{\prime}$ & $2^{\prime}$ & $11^{\prime}$ & $4^{\prime}$ & $4^{\prime}$ & $7^{\prime}$ & $1^{\prime}$ & $1^{\prime}$ & $<1^{\prime}$ \\
\hline Average & $2.5^{\prime}$ & $6^{\prime}$ & $9.7^{\prime}$ & $1.1^{\prime}$ & $6.2^{\prime}$ & $4.5^{\prime}$ & $2.8^{\prime}$ & 7.2' & $2.5^{\prime}$ & $0.8^{\prime}$ & $0.4^{\prime}$ \\
\hline
\end{tabular}

\section{DISCUSSION}

Much of the progress of liver transplantation is due to experimental transplantation programs -which has been one of the ways to train a team specialized in the technical aspects that this procedure requires- as well as conducting research related to transplantations. ${ }^{6,7,8}$

Several animals are used for performing this type of transplantation, the highlight being mice, dogs and pigs. However, mice have anatomical differences when compared to man; besides their small size, they need microsurgical techniques for the performance of anastomoses. Dogs are good specimens, however due to ethical issues, their use in experimental surgery has been diminished. Hence, currently pigs are regarded as the best specimen for liver transplantation. ${ }^{4,9}$

The complete technique of liver transplantation is divided into four parts: 1) liver harvesting from the donor animal; 2) back table; 3) hepatectomy of recipient animal; and 4) implantation of the graft. This study proposes a new technique for liver harvesting in order to reduce the time of organ harvesting. At this stage, there is a greater need for training so that the organ of a donor is not lost, since the duration of the organ ischemia is one of the factors that influences directly the viability of the organ. ${ }^{10}$ 
Vessel dissection was standardized and diverges from that performed by Torres et al. ${ }^{4}$ and Filipone et al. ${ }^{11}$, among other authors. ${ }^{12,}{ }^{13}$ Clockwise handling was adopted in order to facilitate the memorization of a logical sequence, minimizing the occurrence of misconceptions or suppression related to hepatic pedicle handling.

Pneumothorax is performed in order to handle the suprahepatic vena cava. At this stage, the animal starts showing respiratory suffering and the anesthesiologist must increase the oxygen pressure to prevent pulmonary collapse. Pneumothorax caused by the opening of the thoracic cavity can interfere considerably with hematosis, hindering the gas exchange with increased arterial partial pressure of carbon dioxide $\left(\mathrm{PaCO}_{2}\right)$ and decreased arterial partial pressure of oxygen $\left(\mathrm{PaO}_{2}\right)$. This was evidenced by the anesthetic monitoring to which the animals were subjected in this experimental model, in accordance to the findings of similar works in other animals. ${ }^{14}$

Before the section of the suprahepatic vena cava, it is necessary to clamp the hepatic artery, the vena cava and the portal vein. At this stage, the blood flow to the liver is interrupted and the period of ischemia begins. It is important that during this stage the animal receives $10 \mathrm{ml} / \mathrm{Kg}$ of $8.4 \%$ sodium bicarbonate to correct acidosis.

Before removing the liver, the dissection of the ligaments is a special care required with regard to this technique. The liver of pigs has the coronary ligament similar to equines', the sickle cell ligament, which is very short or absent in adults and is attached to the diaphragm, immediately ventral to the foramen of the vena cava, and the round ligament present in young animals. Neither the caudate ligament nor the triangular are present. ${ }^{15}$

It is necessary to be careful when dissecting the ligaments due to their close contact with the diaphragm, since any inadvertent movement can cause the rupture of Glisson's capsule and bleeding in the graft, which could make impossible the implantation on the receiving animal. In order to carry out this section, the first assist should gently pull the liver up and to the left very carefully so not to tear the ligament.

Before starting the irrigation with the preservative solution, the suprahepatic aorta should be ligated, the abdominal aorta tied on the catheter and port and cava veins should be clamped to prevent the solution flowing through the splenic vein and the aorta toward the liver reflow in opposite direction by the portal vein and the vena cava. This way, the preservation solution flows through the liver parenchyma and is eliminated through the suprahepatic vena cava.

During section and withdrawal of the donor graft, it is necessary to be careful at the time of opening the diaphragm from three to four centimeters from the superior vena cava, where a circular cut is made having the referred vessel as the center. This cut is critical in order to have a segment of the diaphragm left around the entire vein, as there are three veins in the diaphragm which need to be ligated via running suture, performed to avoid possible retrograde bleeding after reperfusion of the graft. 
Regarding the donor animal surgery, a reduction of the time spent in the procedure of the transplantations in most operative times was observed. The most time consuming procedure was the dissection of the portal vein, due to the fact that its extent and relationship with other elements of the hepatic pedicle makes handling difficult, with risk of lacerations of its wall or collaterals. According to Torres $(2008)^{16}$, the time of performing vascular dissections was approximately twice and a half more time consuming in relation to this study, showing the advantage of time gain with this new proposal.

\section{CONCLUSION}

The technique of hepatic harvesting described is feasible, effective and reproducible, enabling the training of professionals and academics, as well as the development of future research involving liver transplantation.

\section{REFERENCES}

1. Oliveira DMS, Drachler ML, Oliveira LS. Fatores de risco para a falência do transplante ortópico de fígado no Rio Grande do Sul, Brasil. Cad Saúde Pública. 2007; 23(1): 187-95.

2. Ferraz $\mathrm{BH}$, Afonso RC. Evolução e perspectivas do transplante de fígado no Brasil. Rev Prat Hosp. 2007; 50 (9):167-70.

3. Lacerda CM. Transplante de fígado em hospital universitário do Recife: resultados iniciais. Rev Col Bras Cir. 2003; 30(1): 29-33.

4. Torres OJM. Transplante hepático ortotópico experimental em suínos: resultados iniciais. J Bras Transpl. 2005; 8(2): 305-8.

5. Triviño T, Lopes Filho GJ, Ferraro JR, et al. Instalação e desenvolvimento de um programa de transplante experimental de fígado em porcos. Acta Cir Bras. 1992;7(1):35-7.

6. Zanchet DJ, Montero EFS. Pig liver sectorization and segmentation and virtual reality depiction. Acta Cir Bras. 2002;17(6):381-7.

7. Martins ACA, Machado MAC, Ferraz AAB. Porcine liver: experimental model for the intra-hepatic glissonian approach. Acta Cir Bras. 2008;23(2):204-7.

8. Mariano M. Minissuíno (minipig) na pesquisa biomédica experimental- $O$ minipig. Acta Cir Bras. 2003;18(5):387-91.

9. Hojo, N, Ishibashi T, Yasuda $T$, et al. Porcine model for surgical training of living related liver transplantation. Transplant Proc. 2003; 35: 82-4. 
10. Pokorny $\mathrm{H}$, Langer $\mathrm{F}$, Herkner $\mathrm{H}$, et al. Influence of cumulative number of marginal donor criteria on primary organ dysfunction in liver recipients. Clin Transplant. 2005;19:532-6.

11. Filipponi F, Falcini F, Benassai C, Martini E. Orthotopic liver transplant in pigs: several variations of the surgical technique. G Chir. 1989;10:374-8.

12. Martinez-Ibanez V, Margarit-Creixell $O$, Boix-Ochoa A. A new experimental model of liver transplant in pigs. Ann Esp Pediatr. 1987;26:107-10.

13. Oike F, Uryuhara K, Otsuda M, et al. Simplified technique of orthotopic liver transplantation in pigs. Transplantation. 2001; 71: 328-31.

14. Kallas E, Schnaider TB, Juliano Y, et al. Modelo de anestesia em coelhos para procedimentos no tórax. Acta Cir Bras. 2001; 16(2):91-6.

15. Sisson/Grossman. Anatomia dos animais domésticos. 5 ed. Rio de Janeiro: Guanabara Koogan, 1986. P. 1202.

16. Torres OJM, Pantoja PB, Barbosa ES, et al. Hemodynamics alterations during orthotopic liver experimental transplantation in pigs. Acta Cir Bras. 2008; 23(2): 135-9. 